\title{
The prevalence and associated factors of anxiety and depression symptoms among critical care physicians
}

\section{Powszechność występowania i czynniki towarzyszące objawom lęku i depresji wśród lekarzy oddziałów intensywnej opieki medycznej}

\author{
Katarzyna Białek \\ Institute of Medical Sciences, Jan Kochanowski University, Collegium Medicum, Kielce, Poland
}

Key words: intensive care, critical care, physicians, anxiety, depression, stress.

Słowa kluczowe: intensywna terapia, intensywna opieka medyczna, lęk, depresja, stres.

\begin{abstract}
Introduction: Working in a critical care unit environment may constitute a risk factor for depression and anxiety. Numerous studies have shown a high prevalence of these symptoms among medical critical care staff.

Aim of the research: To assess the level of anxiety and depression and the prevalence of the most stressful factors related to work in the critical care unit.

Material and methods: A total of 89 physicians with various specialties working in critical care units were included. To evaluate the level of anxiety and depression, the standardized Hospital Anxiety and Depression Scale (HADS) was used.

Results: Low to moderate anxiety and depressive symptoms were observed in $25(28.09 \%)$ and $26(29.21 \%)$ respondents, respectively. The score reflecting probable depression and anxiety symptoms was noted in 18 (20.2\%) and 10 (11.2\%) respondents, respectively. The anxiety subscale HADS score was related to gender and professional experience. Age, professional experience, working overtime, and type of hospital were associated with the depression subscale HADS score. The most frequently endorsed stressful factors at work were as follows: the fear of committing an irreversible error (64.0\%), the attitude of patients and their families toward medical staff (58.43\%), and responsibility for another person's life (56.2\%). Regression analysis revealed that sex was the only variable influencing the anxiety subscale score. In the case of depression, no significant factor was identified.

Conclusions: Approximately 1 in 7 physicians presented symptoms of anxiety and/or depression. The next step could be to identify other factors influencing the level of depression and anxiety, focusing on critical care unit staff to prevent and reduce psychopathological symptoms.
\end{abstract}

\section{Streszczenie}

Wprowadzenie: Praca na oddziałach intensywnej opieki medycznej może stanowić czynnik ryzyka wystąpienia lęku i depresji. Liczne badania wykazały powszechność występowania tych objawów wśród personelu medycznego zajmującego się leczeniem krytycznie chorych.

Cel pracy: Ocena poziomu lęku i depresji oraz zidentyfikowanie najbardziej stresujących czynników związanych z pracą na oddziale intensywnej opieki medycznej.

Materiał i metody: Uwzględniono 89 lekarzy różnych specjalności pracujących na oddziałach intensywnej terapii i opieki medycznej. Do oceny poziomu lęku i depresji wykorzystano standaryzowany kwestionariusz Skala lęku i depresji (Hospital Anxiety and Depression Scale-HADS).

Wyniki: Niskie i umiarkowane objawy lęku wykazano odpowiednio u 25 (28,09\%) i 26 (29,21\%) badanych, natomiast wysoki poziom lęku i depresji u $18(20,2 \%)$ i $10(11,2 \%)$ badanych lekarzy. Stwierdzono istotny związek między płcią i doświadczeniem zawodowym a podskalą lęku HADS. Wiek, doświadczenie zawodowe, praca w godzinach nadliczbowych i rodzaj szpitala istotnie korelowały z wynikiem HADS w podskali depresji. Do najczęściej stresujących czynników w pracy należały: lęk przed popełnieniem nieodwracalnego błędu (64,0\%), stosunek pacjentów i ich rodzin do personelu medycznego (58,43\%), odpowiedzialność za życie drugiego człowieka (56,2\%). Analiza regresji wykazała, że jedyną zmienną wpływającą na wynik podskali lęku jest płeć. W przypadku depresji nie stwierdzono zależności statystycznej.

Wnioski: Uwzględniając powyższe wyniki, następnym krokiem powinno być dalsze identyfikowanie czynników wpływających na poziom depresji i lęku wśród lekarzy oddziałów intensywnej opieki medycznej w celu minimalizowania czynników stresujących i zapobiegania wystąpieniu objawów psychopatologicznych w tej grupie. 


\section{Introduction}

Physicians hold the ninth position on the list of the 100 most stressful professions in Poland [1]. However, the nature of a physician's work depends mainly on their professional specialization and their place of work. Professional activity in a hospital differs significantly from work in an outpatient clinic - for example, in Primary Health Care (PHC) counselling or in the field of occupational medicine. Compared to others, specializations characterized by the highest number of stressors include anaesthesiology and intensive therapy, surgery, cardiac surgery, neurosurgery, orthopaedics, or oncology, where critically ill patients are treated, and decisions and therapeutic actions are taken to directly save their lives and health with the use of life support interventions. The situation in these departments is often very dynamic and requires medical personnel to respond quickly and appropriately, especially because every second is important in resolving emergency tasks, and even minor mistakes can have fatal consequences, including the death of the patient. Saving the patient's life, postoperative care, and contact with a seriously ill patient and his/her family all require highly developed interpersonal competencies and an extraordinary degree of cooperation with other staff members. At the same time, working conditions in hospitals are difficult and far from optimal. Work in shifts, night duties, excessive bureaucracy, and inappropriate organization are just some of the aspects that, as well as the responsibility for the life and health of the treated patients, can affect the quality of work. A separate aspect of stress factors is related to sudden and unplanned treatments and aggressive behaviour of the patients and their families, and their attitude towards physicians $[1,2]$. Work in a hospital environment may be satisfying but may also have an adverse effect on the medical staff's physiological and psychological well-being, and may contribute to the occurrence of anxiety and depression.

Several studies have assessed the mental health of intensive care unit physicians. It has been indicated that the prevalence of depressive symptoms among ICU physicians ranged from $10 \%$ to $15 \%$ in the US, Britain, Norway, and Japan [3-7]. Ruitenburg et al. concluded that the prevalence of anxiety and depression was $24 \%$ and $29 \%$ of physicians, respectively [8], while in Chinese studies by Shen et al. [9] and Sun et al. [10], it ranged from 31\% to $65.3 \%$.

In Poland, little is known about symptoms of anxiety and depression among intensive care unit physicians; thus, a systematic comparison is difficult, and the data comprehensively describe far more the issue of professional burnout of ICU medical staff $[11,12]$ rather than recognize the anxiety and depression levels at work, especially of critical care physicians.

\section{Aim of the research}

The aim of the study was to assess the level of anxiety and depression symptoms as well as the frequency of specific stressful factors indicated by critical care physicians related to work where patients in an immediate threat to life and health are treated.

\section{Material and methods}

The research was conducted in Poland between January and February, 2019 among 89 physicians with various specialties working in critical care units in 2 reference centres in a district capital. The Ethics Committee approved the study (4/2019), and all participants gave their written consent. The respondents were informed that they would remain anonymous and the obtained data would be generalized and used only for scientific work. All participants completed the questionnaires through personal contact and face-to-face conversation with the researcher.

For data collection, the authors' questionnaire was used. It included single-choice questions about sex, age, marital status, internship and main workplace in the ward, specialization, work system and overtime work, and a multiple-choice question regarding the most stressful factors at work.

The standardized Hospital Anxiety and Depression Scale (HADS) questionnaire, constructed by Zigmond and Snaith [13] in the Polish version prepared by Majkowicz, de Walden-Gałuszko, and ChojnackaSzawłowska [14] was used to assess the level of anxiety and depression in the study group. According to the authors of the scale, the following standards were adopted for the analysis: 0-7 points - very low, 8-10 points - borderline, more than 10 points - high level of anxiety/depression. According to the primary assumptions of the HADS scale, a high result requires further verification through a full psychiatric examination.

\section{Statistical analysis}

The analysis of quantitative variables was carried out by calculating the mean, standard deviation, median, quartiles, minimum, and maximum, while the analysis of qualitative variables was carried out by calculating the number and percentage of occurrences of each value. The comparison of qualitative variables between groups was made using the $\chi^{2}$ test (with Yates correction for $2 \times 2$ tables) or the exact Fisher test where low expected frequencies appeared. The comparison of quantitative variables in 2 groups was performed using the Student's $t$-test or Mann-Whitney test, and the comparison of the quantitative variables in 3 or more groups was performed by means of the ANOVA or Kruskal-Wallis test. After detection of statistically significant differences, post-hoc analysis was performed using the Fisher's LSD test or Dunn's 
test. Correlations between quantitative variables were analysed using the Pearson or Spearman correlation coefficient. The normality of the variable distribution was examined using the Shapiro-Wilk test. A linear regression model was built to determine the relationship between sociodemographic variables and the scores for anxiety and depression subscales of HADS. The independent variables were age group, sex of respondents, marital status, work experience, type of ward, specialization, overtime, work system, or type of medical centre. A significance level of 0.05 was assumed in the analysis. All analyses were performed in the R software, version 3.5.2 [15].

\section{Results}

Completed questionnaires were obtained from 89 physicians, including $52(58.43 \%)$ men and 37 $(41.57 \%)$ women aged 25 to 64 years. The respondents' mean age was $40.33 \pm 10.29$ years and ranged from 25 to 64 years. Seventy-one out of 89 (79.8\%) participants were in a relationship, $15(16.9 \%)$ respondents were not in a relationship, and $3(3.4 \%)$ respondents did not answer this question. Regarding the ward on which the respondents worked, 26 of them marked the surgical care unit, 24 intensive care unit, 16 worked in the clinic of cardiology and cardiac surgery, 14 in the orthopaedic and trauma care unit, and 9 in the cardiovascular surgery intensive care unit. No paediatricians or neonatologists participated in our study. In total, 51 respondents had worked in the ward for 10 years, 23 had worked between 11 and 19 years, and 15 had worked for 20 years or more. Of the respondents, $59.6 \%$ worked in the 8 -hour system, $15.7 \%$ worked in a 12 - and 24 -hour system, $13.5 \%$ in a 24 -hour system, 5 in a 12-hour system, and 4 in an 8 -, 12-, and 24-hour system. Out of 89 participants, 75 answered that they worked additional hours. The majority of participants worked in teaching hospitals. The above values are presented in Table 1 .

To assess the level of anxiety and depression, the Hospital Anxiety and Depression Scale (HADS) was used. Interpreting the anxiety, it was shown that 46 out of 89 participants declared a score of 7 or lower, 25 respondents had a borderline status - which means that anxiety symptoms are present and more severe than normal - and 18 respondents had a score of 11 and above - which means that anxiety symptoms are severe. In turn, analysing the level of depression, 53 out of 89 participants noted a score of 7 or lower, 26 respondents had a borderline condition, and 10 respondents had a score of 11 and above (Table 2).

It has been noted that the severity of depressive symptoms is significantly and positively correlated with the age of the respondents $(p=0.034)$, so the older the person in the study group, the more severe their depressive symptoms. Anxiety was not correlated with age $(p=0.881)$. Women $(8.05 \pm 3.24)$ had significantly higher anxiety symptoms than men $(6.62 \pm 3.3)$; $(p=0.046)$. There were no significant associations observed between men and women with regard to the level of depression $(p=0.42)$. The data did not reveal any associations in relation to marital status, ward, specialization, and work system. However, significant associations were shown regarding years of service and overtime work. It was noted that persons working in the ward up to 10 and from 11 to 19 years had a significantly higher severity of anxiety symptoms than those working in a ward for 20 years or longer. In turn, people working in the ward for 11-19 years had a significantly higher severity of depressive symptoms than those working in the ward for up to 10 and 20 years and longer (Table 3). In the case of working time, people taking overtime had a significantly higher severity of depressive symptoms than people who did not take additional working hours (Table 4).

The study revealed significant differences in the study group according to work in individual centres. It was noted that physicians working in the district centre had a significantly higher severity of depressive disorders than physicians working in a teaching hospital ( $p=0.037)$.

The respondents were asked to choose the most stressful factors at work. A list of 15 stressful factors was proposed as a multiple-choice question, developed on the basis of previous non-committal conversations with physicians at work. The analysis of quantitative variables was carried out by calculating the number and percentage of the occurrence of each variable. The most frequently endorsed stressful factors at work were as follows: fear of making an irreversible error (64\%), the attitude of patients and their families to medical personnel (58.43\%), responsibility for another person's life (56.2\%), overload with duties $(52.8 \%)$, poor organization of work $(49.5 \%)$, and limited possibility of help for some patients (41.6\%). The above values are classified in Table 5 .

Analysing the most frequently endorsed stressful factors at work in detail, it was noted that the answer "Lack of support from superiors and colleagues" was most often indicated by people over 45 years old and least often by those up to 35 years old. The above values are classified in Table 6.

Including sex of respondents, the answers "Fear of committing an irreversible error" (83.8\%) and "Responsibility for another person's life" (70.2\%) were more often indicated by women $(n=37)$, and "Poor work organization" (59.6\%) by men $(n=52)$.

Significant differences were also noted depending on the type of ward. It was shown that for the doctors working in the cardiology and cardiac surgery clinics, the most frequently endorsed stressful factors at work were related to overloading with duties. This response was given by $87.5 \%$ of doctors in these de- 
Table 1. Data of the studied group

\begin{tabular}{|c|c|c|c|c|c|c|c|}
\hline \multicolumn{4}{|l|}{ Parameter } & \multicolumn{2}{|c|}{$N$} & \multicolumn{2}{|c|}{$\%$} \\
\hline \multirow[t]{5}{*}{ Ward } & \multicolumn{3}{|c|}{ Anaesthesiology and intensive care } & \multicolumn{2}{|c|}{24} & \multicolumn{2}{|c|}{26.97} \\
\hline & \multicolumn{3}{|c|}{ Cardiovascular intensive care } & \multicolumn{2}{|c|}{9} & \multicolumn{2}{|c|}{10.11} \\
\hline & \multicolumn{3}{|l|}{ Surgical care unit } & \multicolumn{2}{|c|}{26} & \multicolumn{2}{|c|}{29.21} \\
\hline & \multicolumn{3}{|c|}{ Clinic of cardiology and cardiac surgery } & \multicolumn{2}{|c|}{16} & \multicolumn{2}{|c|}{17.98} \\
\hline & \multicolumn{3}{|c|}{ Orthopaedic and trauma care unit } & \multicolumn{2}{|c|}{14} & \multicolumn{2}{|c|}{15.73} \\
\hline \multirow[t]{2}{*}{ Age [years] } & Mean & SD & Median & Min. & Max. & Q1 & Q3 \\
\hline & 40.33 & 10.29 & 38 & 25 & 64 & 31 & 47 \\
\hline \multicolumn{4}{|l|}{ Parameter } & \multicolumn{2}{|c|}{$n$} & \multicolumn{2}{|c|}{$\%$} \\
\hline \multirow[t]{2}{*}{ Sex } & \multicolumn{3}{|l|}{ Women } & \multicolumn{2}{|c|}{37} & \multicolumn{2}{|c|}{41.57} \\
\hline & \multicolumn{3}{|l|}{ Men } & \multicolumn{2}{|c|}{52} & \multicolumn{2}{|c|}{58.43} \\
\hline \multirow[t]{3}{*}{ Marital status } & \multicolumn{3}{|l|}{ In relationship } & & & & \\
\hline & Not in relationship & & & & & & \\
\hline & No answer & & & & & & \\
\hline Experience & Employed for up to 10 & & & & & & \\
\hline & $11-19$ years & & & & & & \\
\hline & 20 years and more & & & & & & \\
\hline Work system & $8-h$ & & & & & & \\
\hline & 8-, 12-, and 24-h & & & & & & \\
\hline & $12-\mathrm{h}$ & & & & & & \\
\hline & 12- and 24-h & & & & & & \\
\hline & 24-h & & & & & & \\
\hline & No answer & & & & & & \\
\hline Overtime & Overtime & & & & & & \\
\hline & No overtime & & & & & & \\
\hline & No answer & & & & & & \\
\hline
\end{tabular}

Table 2. The level of anxiety and depression of physicians in the examined group measured by the Hospital Anxiety and Depression Scale (HADS)

\begin{tabular}{|lcccc|}
\hline Variable & & HADS interpretation & $n$ & $\%$ \\
\cline { 2 - 5 } Anxiety & $0-7$ & No disorders & 46 & 51.69 \\
\cline { 2 - 5 } & $8-10$ & Border state & 25 & 28.09 \\
\hline Depression & $11-21$ & Anxiety symptoms & 18 & 20.22 \\
& $0-7$ & No disorders & 53 & 59.55 \\
\cline { 2 - 5 } & $8-10$ & Border state & 26 & 29.21 \\
\hline
\end{tabular}

partments $(n=16)$. Interestingly, this factor was the least frequently indicated by people working in the orthopaedic care unit (26.8\%).

On the other hand, the answer "No support from supervisors and colleagues" was most often (62.5\%) declared by physicians working in the ICU $(n=24)$, and least often (12.5\%) by physicians working in the cardiology and cardiac surgery ward.

It was also examined whether the work experience in a particular ward may affect a given stressor's subjective feeling. The responses "Fear of committing an irreversible error" and "The attitude of patients and 
Table 3. The level of anxiety and depression in the examined group in relation to work overtime taken

\begin{tabular}{|c|c|c|c|c|c|}
\hline HADS & & $\begin{array}{l}\text { Up to } 10 \text { years } \\
(n=51)-A\end{array}$ & $\begin{array}{l}\text { 11-19 years } \\
(n=23)-B\end{array}$ & $\begin{array}{c}20 \text { years and more } \\
(n=15)-C\end{array}$ & $P$-value* \\
\hline \multirow[t]{3}{*}{ Anxiety } & Mean \pm SD & $7.25 \pm 3.03$ & $8.48 \pm 3$ & $5.2 \pm 4$ & 0.011 \\
\hline & Median & 7 & 8 & 4 & $P$ \\
\hline & Quartiles & $5-9.5$ & $7.5-11$ & $2.5-7.5$ & $B, A>C$ \\
\hline \multirow[t]{3}{*}{ Depression } & Mean \pm SD & $5.37 \pm 3.58$ & $8 \pm 4.12$ & $5.4 \pm 4.26$ & 0.021 \\
\hline & Median & 5 & 9 & 4 & NP \\
\hline & Quartiles & $2-9$ & $4.5-10.5$ & $2.5-9$ & $B>C, A$ \\
\hline
\end{tabular}

${ }^{*} P-$ Normal distribution in groups, ANOVA + post-hoc analysis results (Fisher LSD test), NP - lack of normality of distribution in groups, Kruskal-Wallis test + post-hoc results (Dunn test).

Table 4. The level of anxiety and depression in the examined group in relation to work overtime taken

\begin{tabular}{|lcccc|}
\hline HADS & & Overtime $(n=75)$ & No overtime $(n=12)$ & $P_{\text {-value* }}$ \\
\cline { 2 - 5 } Anxiety & Mean \pm SD & $7.16 \pm 3.46$ & $7.04 \pm 2.47$ & 0.91 \\
\cline { 2 - 5 } & Median & 8 & 7 & $P$ \\
\hline \multirow{2}{*}{ Depression } & Quartiles & $5-10$ & $5-7.5$ & 0.049 \\
& Mean \pm SD & $6.27 \pm 3.83$ & $4.07 \pm 4.43$ & NP \\
\cline { 2 - 5 } & Median & 7 & 2 & $1-5.25$ \\
\hline
\end{tabular}

${ }^{*} P-$ Normal distribution in groups, Student's t test, NP- No normality of distribution in groups, Mann-Whitney test.

their families to medical staff" were most often indicated by physicians working 11-19 years and the least frequently by those working 20 years and more. In turn, the answer "Others" was most often indicated by physicians working 20 years and longer and the least often in those employed for up to 10 years. The above values are classified in Table 7.

Interesting results were also obtained regarding the work system and overtime taken in the studied group. It was noted that the answer "Lack of support from supervisors and colleagues" (48.6\%) was more often declared by physicians working in a system different than 8-hour, i.e. 12- and 24-hour $(n=35)$. $P$-values lower than 0.05 also indicate significant differences between groups regarding overtime taken. The present study revealed that the answer "poor work organization" (54.7\%) was most often indicated by people working overtime $(n=75)$.

Marital status, specialization, and type of medical centre were not associated with the most stressful factors.

The linear regression model revealed the influence of only female gender on the scale of anxiety score of HADS $(p<0.05)$. In comparison to female gender, male gender reduced it by 1.824 points on average. The $R^{2}$ coefficient was $15.93 \%$, which means that $15.93 \%$ of the variability of the score on the anxiety scale was explained by variables taken into the model. The remaining $84.07 \%$ depend on variables in the not
Table 5. The most frequently endorsed stressful factors at work

\begin{tabular}{|lcc|}
\hline The most stressful factors at work & $N$ & $\%^{*}$ \\
Fear of committing an irreversible error & 57 & 64.04 \\
$\begin{array}{l}\text { Responsibility for the life of another } \\
\text { human being }\end{array}$ & 50 & 56.18 \\
Overloading duties & 47 & 52.81 \\
Limited possibility of help some patients & 37 & 41.57 \\
Danger of personal safety & 8 & 8.99 \\
Communion with suffering & 11 & 12.36 \\
Communion with death & 8 & 8.99 \\
$\begin{array}{l}\text { Lack of support from superiors and } \\
\text { colleagues }\end{array}$ & 27 & 30.34 \\
Contact with the patient's family & 19 & 21.35 \\
Breaking bad news to the patient's family & 21 & 23.60 \\
Bad work organization & 44 & 49.44 \\
Sudden and unplanned treatments and & 14 & 15.73 \\
surgeries & & \\
Resuscitation & 8 & 8.99 \\
Difficult intubation & 7 & 7.87 \\
The attitude of patients and their & 52 & 58.43 \\
families to medical staff & & 6.74 \\
\hline Others & 6 & \\
\hline
\end{tabular}


Table 6. The most frequently endorsed stressful factors in relation to age

\begin{tabular}{|lcccc|}
\hline Variable & $\begin{array}{c}\text { Up to 35 years } \\
(n=35)\end{array}$ & $\begin{array}{c}\text { 36-45 years } \\
(n=26)\end{array}$ & $\begin{array}{c}46 \text { years and } \\
\text { more }(n=28)\end{array}$ & $P_{\text {-value }}$ \\
Fear of committing an irreversible error & $24(68.57)$ & $18(69.23)$ & $15(53.57)$ & $0.377 \chi^{2}$ \\
Responsibility for the life of another human being & $21(60.00)$ & $16(61.54)$ & $13(46.43)$ & $0.451 \chi^{2}$ \\
Overloading duties & $19(54.29)$ & $15(57.69)$ & $13(46.43)$ & $0.692 \chi^{2}$ \\
Limited possibility of help for some patients & $12(34.29)$ & $15(57.69)$ & $10(35.71)$ & $0.139 \chi^{2}$ \\
Danger of personal safety & $5(14.29)$ & $2(7.69)$ & $1(3.57)$ & $0.332 \mathrm{~F}$ \\
Communion with suffering & $4(11.43)$ & $3(11.54)$ & $4(14.29)$ & $1 \mathrm{~F}$ \\
Communion with death & $5(14.29)$ & $2(7.69)$ & $1(3.57)$ & $0.332 \mathrm{~F}$ \\
Lack of support from superiors and colleagues & $5(14.29)$ & $9(34.62)$ & $13(46.43)$ & $0.019 \chi^{2}$ \\
Contact with the patient's family & $7(20.00)$ & $4(15.38)$ & $8(28.57)$ & $0.482 \chi^{2}$ \\
Breaking bad news to the patient's family & $8(22.86)$ & $5(19.23)$ & $8(28.57)$ & $0.715 \chi^{2}$ \\
Bad work organization & $18(51.43)$ & $12(46.15)$ & $14(50.00)$ & $0.918 \chi^{2}$ \\
Sudden and unplanned treatments and surgeries & $8(22.86)$ & $5(19.23)$ & $1(3.57)$ & $0.078 \mathrm{~F}$ \\
\hline Resuscitation & $5(14.29)$ & $2(7.69)$ & $1(3.57)$ & $0.332 \mathrm{~F}$ \\
\hline Difficult intubation & $3(8.57)$ & $2(7.69)$ & $2(7.14)$ & $1 \mathrm{~F}$ \\
The attitude of patients and their families to medical staff & $18(51.43)$ & $17(65.38)$ & $17(60.71)$ & $0.526 \chi^{2}$ \\
\hline Others & $1(2.86)$ & $2(7.69)$ & $3(10.71)$ & $0.434 \mathrm{~F}$ \\
\hline
\end{tabular}

${ }^{*} \chi^{2}-$ chi-square test, $F$ - Fisher's exact test.

Table 7. The most frequently endorsed stressful factors in relation to work experience

\begin{tabular}{|lcccc|}
\hline Variable & $\begin{array}{c}\text { Up to 10 years } \\
(n=51)\end{array}$ & $\begin{array}{c}11-19 \text { years } \\
(n=23)\end{array}$ & $\begin{array}{c}\text { 20 years and } \\
\text { more }(n=15)\end{array}$ & $P$-value* \\
Fear of committing an irreversible error & $34(66.67)$ & $18(78.26)$ & $5(33.33)$ & $0.016 \chi^{2}$ \\
Responsibility for the life of another human being & $32(62.75)$ & $11(47.83)$ & $7(46.67)$ & $0.351 \chi^{2}$ \\
Overloading duties & $24(47.06)$ & $15(65.22)$ & $8(53.33)$ & $0.35 \chi^{2}$ \\
Limited possibility of help for some patients & $22(43.14)$ & $9(39.13)$ & $6(40.00)$ & $0.94 \chi^{2}$ \\
Danger of personal safety & $5(9.80)$ & $2(8.70)$ & $1(6.67)$ & $1 \mathrm{~F}$ \\
Communion with suffering & $5(9.80)$ & $3(13.04)$ & $3(20.00)$ & $0.492 \mathrm{~F}$ \\
Communion with death & $6(11.76)$ & $1(4.35)$ & $1(6.67)$ & $0.686 \mathrm{~F}$ \\
Lack of support from superiors and colleagues & $11(21.57)$ & $11(47.83)$ & $5(33.33)$ & $0.078 \mathrm{~F}$ \\
Contact with the patient's family & $9(17.65)$ & $6(26.09)$ & $4(26.67)$ & $0.592 \mathrm{~F}$ \\
Breaking bad news to the patient's family & $10(19.61)$ & $5(21.74)$ & $6(40.00)$ & $0.276 \mathrm{~F}$ \\
Bad work organization & $25(49.02)$ & $15(65.22)$ & $4(26.67)$ & $0.067 \chi^{2}$ \\
Sudden and unplanned treatments and surgeries & $11(21.57)$ & $2(8.70)$ & $1(6.67)$ & $0.281 \mathrm{~F}$ \\
Resuscitation & $6(11.76)$ & $1(4.35)$ & $1(6.67)$ & $0.686 \mathrm{~F}$ \\
Difficult intubation & $4(7.84)$ & $1(4.35)$ & $2(13.33)$ & $0.745 \mathrm{~F}$ \\
The attitude of patients and their families to medical staff & $27(52.94)$ & $19(82.61)$ & $6(40.00)$ & $0.016 \chi^{2}$ \\
Others & $1(1.96)$ & $2(8.70)$ & $3(20.00)$ & $0.024 \mathrm{~F}$ \\
\hline
\end{tabular}

${ }^{*} \chi^{2}-$ chi-square test, $F-$ Fisher's exact test. 
included model and on random factors. However, the observed correlation is very weak and thus should be considered with caution. None of the analysed features are an independent predictor of the outcome on the depression scale score, and the $R^{2}$ coefficient was $20.95 \%$ for this model.

\section{Discussion}

As expected, this study reported a high rate of anxiety and depressive symptoms among critical care physicians. In the present study, the symptoms of depression were related to poor work organizational factors, such as workload and overtime taken by doctors. It has been clearly demonstrated that physicians taking overtime have a significantly higher levels of depression than people who do not take extra hours of work.

This is associated with a study in which it was shown that the factor influencing the occurrence of anxiety and depression was related to the number of hours worked per week and the number of beds in the ICU of which the doctors were in charge [16]. Moreover, physicians who work at least $60 \mathrm{~h}$ per week or who work night shifts twice or more per week were at greater risk of experiencing anxiety and depressive symptoms [17]. Coomber et al. [3] noted that as many as $10 \%$ of the surveyed physicians working in ICUs had clinically significant depressive symptoms related to the number of hours of work per week.

The influence of working time was also described by Howard [cf. 18], who first of all noticed permanent fatigue of doctors resulting from long working hours. The study showed that excessive fatigue and highlevel stress increase the incidence of mistakes made by anaesthesiologists, which also negatively affects the quality of their medical care. Additionally, it has been shown that ICU physicians made $36 \%$ more serious medical errors in the ICU when they frequently worked shifts of $24 \mathrm{~h}$ or more compared to when they worked shorter shifts [19] and the time to intubate the trachea was significantly longer during a night shift than during the day [20]. The observed positive associations between very long working hours or too frequent night shifts within a short period of time and symptoms of anxiety or depression should be carefully considered by hospital administrators responsible for preparing physicians' schedules.

Overload with duties means that medical staff of critical care units are also a group exposed to somatic costs. An example of health complications among physicians is provided by Gębska-Kuczerowska [21]. The most frequently reported complaints were as follows: arrhythmias (78\%), sleep regulation disorders $(62 \%)$, headaches $(56 \%)$, ischaemic heart disease and unstable arterial pressure (53\%), complaints associated with exacerbation of chronic disease of joints $(83 \%)$, and decrease in efficiency and concentration disorders (57\%). Therfore, ICU organizational aspects are very important and could be a major issue in decreasing physicians' distress and depression [3].

It is very interesting to notice that the physicians included in the present study with higher anxiety symptoms had a shorter practice (employed for up to 10 years and 11-19 years) compared with those who had a longer experience. Physicians with a mediumlength practice (11-19 years) had higher depressive symptoms than experienced physicians employed for up 10 years or 20 years and more. It may suggest that distress or the prevalence of anxiety and depression in intensivists are "occupational hazards" that can strike at any time in an ICU career. It can be assumed that in the case of physicians earlier in their practice, the contact with death and seriously ill people is still a strong experience, the negative emotions and reactions of which may hinder the development of constructive strategies for coping with difficult situations. In contrast, physicians with more experience approach it with a greater distance and have a better developed ability to cope with stress. The above assumption is in accord with the study of Kousha et al. [22], which showed that stress, anxiety, and depression were stronger among resident doctors under 30 years old with very short work experience in the ICU.

The sex of the subjects is also important for the occurrence of anxiety and depression. In the present study, women had significantly higher levels of anxiety than men. Women more frequently declared their fear of making an irreversible error and responsibility for another person's life. Frank and Dingle [16] also reported that female physicians with depression were more dissatisfied with their career or workplace.

The analysis performed by other Polish authors also contributed to the discussion of stress factors at ICU physicians' workplace [18]. The most stressful factors listed include, among others, sudden and severe condition of the patient, difficulties in making the right diagnosis, chronic diseases, and physicians' skills of breaking bad news to patients' relatives. Further studies mentioned difficult intubation, poor work organization, resuscitation, poor chance for recovery of that patient's condition, work under time pressure, the need to make quick and error-free decisions, extra duties outside the main workplace, lack of social recognition, and low prestige of the profession relative to other specialties [12].

Interpreting stress factors in the physicians' work, and the attitude of patients and their families towards the medical staff seems to be of great importance. Zafar et al. [23] have shown that as many as 1 in 6 physicians working in emergency departments experience a physical attack from the patient, and 3 out of 5 doctors were victims of verbal abuse (insults, threats, blackmail). Physicians who experi- 
enced workplace violence on the part of the patient or their family were nearly 7 times more likely to be depressed compared to those who did not encounter it. Previous studies also demonstrated that workplace violence increases the prevalence of psychological conditions such as anxiety and depression among exposed physicians [24, 25]. Additionally, contact with an aggressive patient and his/her family may also be related to increased risk of post-traumatic stress disorder (PTSD) [23].

Some publications are even specifically targeted at assessing the risk and incidence of post-traumatic stress disorder among physicians working in the critical care unit. In such a stressful environment, secondary traumatization may be a significant consequence of work, and the depression described above, suicidal thoughts, or anxiety disorders may be a high risk of PTSD. Studies have shown that $12-33 \%$ of physicians working in ICUs meet the overall criteria of PTSD, and $30 \%$ have one or more symptoms. What is more, these symptoms are positively correlated with age, which means that the more years of work, the more severe may be the symptoms of PTSD [26]. In some other studies, it was noted that as many as $28 \%$ of ICU physicians experienced nightmares in relation to their work, and the most common causes were breaking bad news to the patient's family and end-of-life care [23]

Additionally, the novel SARS-CoV-2 pandemic may be a crucial stress factor and may result in an overall surge in new cases of anxiety, depression, and burnout in critical health care physicians. It is recognized that the COVID-19 pandemic is putting healthcare ICU professionals under extreme pressure. Regarding ICU specialists' mental health outcomes during the COVID-19 outbreak, the prevalence of anxiety, depression, and severe burnout symptoms were $46.5 \%, 30.2 \%$, and 51\%, respectively [27]. Factors associated with an increase of anxiety and depression symptoms were female gender, younger age, living in a city of $>1$ million inhabitants, higher religiosity, and not being in a relationship.

The results presented above justify that the risk of anxiety and/or depression symptoms among physicians in critical care units is high. The study has shown that poor ICU functioning is significant, requiring the implementation of appropriate preventive measures to ensure mental comfort for doctors and, indirectly, for patients and their families. The examination of doctors' needs seems to be crucial. The next step should be to implement all kinds of interventions and support programs in order to decrease negative emotions, recognize and reduce the symptoms and effects of stress, and learn to cope with difficult situations. The inclusion of a psychologist in the work of the unit seems to be helpful. Health professionals and their superiors should be aware of the negative psychological effects resulting from clinical practice that may cause impairment in social, occupational, or other important areas of functioning.

This study has several limitations. First of all, a relatively small sample of 89 examined doctors limits the representativeness of the results and the statistical power of the analyses obtained. No trend should be extrapolated to a broader (or general) population from such a small sample. Therefore, the results must be interpreted with caution.

The strength of the study is its aim. Not many studies concerning anxiety and depression among physicians in general and ICU workers, in particular, are available. Secondly, a 100\% response rate was achieved, and almost no missing information and unanswered questions were found in any questionnaire.

\section{Conclusions}

Our findings show that 18 examined physicians had anxiety symptoms and in 10 responders there were depressive symptoms above 11 points in the HADS score. Respondents taking overtime had significantly higher severity of depressive disorders than physicians who did not work overtime. Female gender was the only variable influencing the anxiety subscale HADS score. The most frequently endorsed stressful factors at work were as follows: fear of making an irreversible error, the attitude of patients and their families to medical personnel, responsibility for the life of another person, overloading duties, poor work organization, and limited possibility of help for some patients. For women, the most stressful was the fear of committing an irreversible error and responsibility for another person's life; for men it was poor work organization. The fear of committing an irreversible error and patients and their families' attitude to medical personnel were most often indicated as stressful by persons working 11-19 years and the least frequently by persons working 20 years and more. For physicians working in a 12-hour and 24-hour system, the lack of support from superiors and colleagues was the most stressful, while the poor work organization turned out to be the most stressful factor for people taking overtime.

\section{Conflict of interest}

The author declares no conflict of interest.

\section{References}

1. Irzyniec T, Konodyba-Szymański P, Szczerba H. Identyfikacja zagrożeń oraz ocena ryzyka zawodowego lekarzy medycyny (wstępne wyniki). J Ecol Health 2010; 14: 295-302.

2. Piquette D, Reeves S, LeBlanc VR. Stressful intensive care unit medical crises: How individual responses impact on team performance. Crit Care Med 2009; 37: 1251-1255. 
3. Coomber S, Todd C, Park G, Baxter P, Firth-Cozens J, Shore S. Stress in UK intensive care unit doctors. $\mathrm{Br}$ J Anaesth 2002; 89: 873-881.

4. Ofili AN, Asuzu MC, Isah EC, Ogbeide O. Job satisfaction and psychological health of doctors at the University of Benin Teaching Hospital. Occup Med 2004; 54: 400-403.

5. Schwenk TL, Gorenflo DW, Leja LM. A survey on the impact of being depressed on the professional status and mental health care of physicians. J Clin Psychiatry 2008; 69: 617-620.

6. Vaglum P, Falkum E. Self-criticism, dependency and depressive symptoms in a nationwide sample of Norwegian physicians. J Affect Disord 1999; 52: 153-159.

7. Wada K, Yoshikawa T, Goto T, Hirai A, Matsushima E, Nakashima Y, Akaho R, Kido M, Hosaka T. Association of depression and suicidal ideation with unreasonable patient demands and complaints among Japanese physicians: a national cross-sectional survey. Int J Behav Med 2011; 18: 384-390.

8. Ruitenburg MM, Frings-Dresen MH, Sluiter JK. The prevalence of common mental disorders among hospital physicians and their association with self-reported work ability: a cross-sectional study. BMC Health Serv Res 2012; 12: 292-298.

9. Shen LL, Lao LM, Jiang SF, Yang H, Ren LM, Ying DGC, Zhu SZ. A survey of anxiety and depression symptoms among primary-care physicians in China. Int J Psychiatry Med 2012; 44: 257-270.

10. Sun W, Fu J, Chang Y, Wang L. Epidemiological study on risk factors for anxiety disorder among Chinese doctors. J Occup Health 2012; 54: 1-8.

11. Kotarba A, Borowiak E. Stress coping styles and occupational burnout syndrome of nurses employed in intensive care units. Nursing 21st Century 2018; 17: 12-17.

12. Kwiatosz-Kuc M, Fijałkowska-Nestorowicz A, Fijałkowska M, Aftyka A, Pietras P, Kowalczyk M. Stress coping styles among anaesthesiology and intensive care unit personnel - links to the work environment and personal characteristics: a multicentre survey study. Scand J Caring Sci 2019; 33: 661-668.

13. Zigmond AS, Snaith RP. The hospital anxiety and depression scale. Acta Psychiatr Scand 1983; 67: 361-370.

14. Majkowicz M, de Walden-Gałuszko K, Chojnacka-Szawłowska G. Ocena jakości opieki paliatywnej w teorii i praktyce. In: Ocena jakości opieki paliatywnej w teorii i praktyce. de Walden-Gałuszko K, Majkowicz M (eds.). Akademia Medyczna. Zakład Medycyny Paliatywnej, Gdańsk 2000; 21-42.

15. R Core Team (2018). R: A language and environment for statistical computing. R Foundation for Statistical Computing, Vienna, Austria. URL https://www.R-project.org/

16. Frank E, Dingle AD. Self-reported depression and suicide attempts among U.S. women physicians. Am J Psychiatry 1999; 156: 1887-1894.

17. Gong Y, Han T, Chen W, Dib HH, Yang G, Zhuang R, Chen Y, Tong X, Yin X, Lu Z. Prevalence of anxiety and depressive symptoms and related risk factors among physicians in China: a cross-sectional study. PLoS One 2014; 9: e103242.

18. Pawełczak E, Gaszyński T. Sytuacje stresogenne w zawodzie lekarza anestezjologa i pielęgniarki anestezjologicznej. Anest Ratow 2013; 7: 19-26.
19. Landrigan CP, Rothschild JM, Cronin JW, Kaushal R, Burdick E, Katz JT, Lilly CM, Stone PH, Lockley SW, Bates DW, Czeisler CA. Effect of reducing interns' work hours on serious medical errors in intensive care units. N Engl J Med 2004; 351: 1838-1848.

20. Smith-Coggins R, Rosekind MR, Buccino KR, Dinges DF, Moser RP. Rotating shiftwork schedules: can we enhance physician adaptation to night shifts? Acad Emerg Med 1997; 4: 951-961.

21. Gębska-Kuczerowska W. Wypalenie zawodowe lekarzy jako problem i wyzwanie dla zdrowia publicznego. Narodowy Instytut Zdrowia Publicznego - Państwowy Zakład Higieny. Warszawa 2011; 106-111.

22. Kousha M, Bagheri HA, Heydarzadeh A. Emotional intelligence and anxiety, stress, and depression in Iranian resident physicians. J Family Med Prim Care 2018; 7: 420-424.

23. Zafar W, Khan UR, Siddiqui SA, Jamali S, Razzak JA. Workplace violence and self-reported psychological health: coping with post-traumatic stress, mental distress, and burnout among physicians working in the emergency departments compared to other specialities in Pakistan. J Emerg Med 2016; 50: 167-177.

24. Aytac S, Dursun S. The effect on employees of violence climate in the workplace. Work 2012; 41: 3026-3031.

25. Merecz D, Drabek M, Moscicka A. Aggression at the workplace - psychological consequences of abusive encounter with coworkers and clients. Int J Occup Med Environ Health 2009; 22: 243-260.

26. De Boer J, Lok A, Verlaat E, Duivenvoorden HJ, Bakker AB, Smit BJ. Work-related critical incidents in hospital-based health care providers and the risk of post-traumatic stress symptoms, anxiety, and depression: a meta-analysis. Soc Sci Med 2011; 73: 316-326.

27. Azoulay E, De Waele J, Ferrer R, Staudinger T, Borkowska M, Povoa P, Iliopoulou K, Artigas A, Schaller SJ, Hari MS, Pellegrini M, Darmon M, Kesecioglu J, Cecconi M, ESICM. Symptoms of burnout in intensive care unit specialists facing the COVID-19 outbreak. Ann Intensive Care 2020; 10: 110.

\section{Address for correspondence:}

\section{Katarzyna Białek}

Institute of Medical Sciences

Jan Kochanowski University

Collegium Medicum

Kielce, Poland

Phone: +48 512318732

E-mail: katarzynabialek@vp.pl 